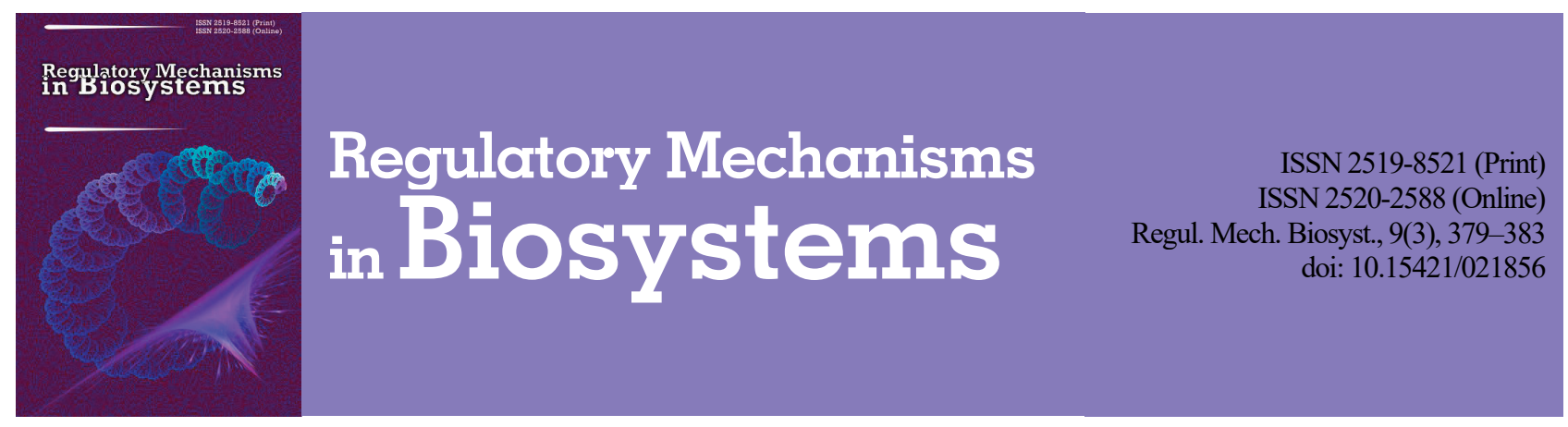

\title{
Changes in erythrocytopoesis indices in dogs with babesiosis
}

\author{
V. I. Holovakha*, O. V. Piddubnyak*, T. I. Bakhur*, N. V. Vovkotrub*, A. A. Antipov*, M. V. Anfiorova**, \\ B. V. Gutyj***, L. G. Slivinska***, O. P. Kurdeko****, A. O. Macynovich**** \\ *Bila Tserkva National Agrarian University, Bila Tserkva, Ukraine \\ **Odessa State Agrarian University, Odessa, Ukraine \\ ***Stepan Gzhytskyi National University of Veterinary Medicine and Biotechnologies, Lviv, Ukraine \\ ****Vitebsk Order of the Badge of Honor State Academy of Veterinary Medicine, Vitebsk, Belarus Republic
}

Article info

Received 20.07.2018

Received in revised form 28.08 .2018

Accepted 02.09.2018

Bila Tserkva National Agrarian University

Pl. Soborna, 8/1,

Bila Tserkva, 09117, Ukraine.

Tel.: +38-067-693-17-73.

Odessa State Agrarian University,

Krasnova st., 3a, Odessa, 65010, Ukraine.

Tel.: +38-048-765-93-17.

E-mail:odau_vetmed@ukr.net

Stepan Gzhytskyi National University

of Veterinary Medicine and Biotechnologies

Lviv, Pekarska st., 50, Lviv, 79010, Ukraine.

Tel.: + 38-097-290-41-51.

E-mail:maksymovych@lvet.edu.ua

Vitebsk Order of the Badge of Honor

State Academy of Veterinary Medicine,

1st Dovator st., 7/11, Vitebsk, 210026,

Belarus Republic.

E-mail:vsavm@vsavm.by
Holovakha, V. I., Piddubnyak, O. V., Bakhur, T. I., Vovkotrub, N. V., Antipov, A. A., Anfiorova, M. V., Gutyj, B. V., Slivinska, L. G., Kurdeko, O. P., \& Macynovich, A. O. (2018). Changes in erythrocytopoesis indices in dogs with babesiosis. Regulatory Mechanisms in Biosystems, 9(3), 379-383. doi:10.15421/021856

Babesiosis is a common disease in dogs. Babesia canis (Piana \& Galli-Valerio, 1895) (Sporozoa, Babesiidae) causes the destruction of erythrocytes, resulting in hypotensive shock and total tissue damage due to lack of oxygen. Because of babesiosis, anemia develops in dogs, and in the first hours of the disease it is normocytic, normochromic and nonregenerative, and on the 2-3rd day of the course, macrocytic, hypochromic anemia with reticulocytosis develops. Scientists have studied the most common indicators of evaluation of erythrocytopoesis during babesiosis (the number of red blood cells, hemoglobin, hematocrit index, indices of "red" blood MCH and MCV), but the age structure of erythrocytes, their acid resistance and the ferrum-transferrin complex for this parasitic pathology have not been sufficiently studied. We carried out research on dogs of service breeds, which were divided into two groups: the first (618 months old, $n=10)$ and the second $(2-8$ years, $n=15)$. According to the conducted studies, in dogs of different age groups with babesiosis revealed oligocythemia with anisocytosis and poikilocytosis, oligochromia, decreased hematocrit index and macrocytosis. Significant changes in the morpho-functional state of erythrocytes in dogs of both groups have been revealed, in particular, changes in the population (age) composition of red blood cells: the number of "old" erythrocytes increases (they are rapidly destroyed), the "young" forms of red blood cells decrease and the time for their hemolysis is reduced. As a result of the study of the ferrum-transferrin complex in dogs with babesiosis in both groups, an increase in the level of free ferrum (UIBC) and a decrease in the saturation of transferrin with the trace element was found, which makes it impossible to form a hemoglobin molecule in the bone marrow.

Keywords: erythrocytes; population composition of erythrocytes; acid resistance; hemoglobin; MCN; MCV; ferrum; transferring; ferrum-transferrin complex.

\section{Introduction}

One of the most common diseases in dogs is babesiosis. Areas of infection are found in the tropics (Jain et al., 2017; Ybañez et al., 2018), Mediterranean countries (Salem \& Farag, 2014), Eastern (Davitkov et al., 2015; Bartnicki et al., 2017) and Western Europe (Eichenberger et al., 2016), Asia (Liu et al., 2016; Wang et al., 2018) and America (Di Cicco et al., 2012; Rojas et al., 2014). The analysis of recent publiccations proves that babesiosis in dogs occurs in almost all regions of Ukraine (in 18 of 24). The territory of six regions (mostly Southern and Steppe zones of Ukraine) remain free of this invasion. The infestation of dogs occurs during an attack of ixodid ticks (Arachnoidea, Ixodidae) and exposure of the pathogen with their saliva to a susceptible animal (Bajer et al., 2014).

Metabolites of Babesia canis (Piana \& Galli-Valerio, 1895) (Sporozoa, Babesiidae), accumulating in erythrocytes, cause disorders of blood, nervous and cardiovascular systems, the gastrointestinal tract, liver, kidneys, etc. (Lobetti et al., 2012; Zygner et al., 2012; Tasaki et al., 2013). Parasites cause destruction of red blood cells, resulting in hypotensive shock and total tissue damage due to lack of oxygen (Goddard et al., 2015). Because of babesiosis in dogs, anemia appears, which is normocytic, normochromic and non-regenerative in the first hours of the disease. On the 2-3rd days of the course of the disease, macrocytic, hypochromic anemia with reticulocytosis develops.

Sources from the literature usually describe the most common indicators of evaluation of erythrocytopoesis during babesiosis (the number of erythrocytes, hemoglobin, hematocrit index, indices of "red" blood-MCH and MCV).

However, data are absent on the changes in other indicators of evaluation of erythrocytopoesis in the course of this parasitic pathology: the red blood cells' age structure, their acid resistance and the ferrumtransferin complex (FTC). Therefore, the purpose of this article is to study the changes in age composition of erythrocytes, their acid resistance and indicators of FTC in dogs with babesiosis.

\section{Materials and methods}

The objects of the study were dogs of service breeds, which were divided into two groups: the first (age from 6 to 18 months, $n=10$ ) and the second one (from 2 to 8 years old, $\mathrm{n}=15$ ). Blood samples were taken in vacuum tubes of $10 \mathrm{ml}$ volume (Vacutest, Italy). An anticoagulant ethylendiaminetetraacetic acid (EDTA) was used for blood tests.

In the dogs' blood, the total number of erythrocytes, hemoglobin content, hematocrit, MCV (average volume of erythrocyte) was deter- 
mined by an automatic hematological analyzer Mythic 18 (Orphee S.A., Switzerland) and reagents by PZ Cormay S.A. (Poland). MCH (hemoglobin content in erythrocyte) was calculated mathematically.

Acid resistance of erythrocytes was determined by the method of A. I. Terskov and I. I. Hitelzon. Blood for research was taken into centrifuge tubes, where heparin was pre-added at a rate of $10 \mathrm{IU}$ per $10 \mathrm{ml}$ of blood. The plasma was separated by centrifugation $(1,500 \mathrm{rpm}$ for 20 minutes). The erythrocyte suspension was thoroughly cleaned with $0.85 \%$ sodium chloride solution, cooled to $4{ }^{\circ} \mathrm{C}$ (to prevent oxidation of the lipoproteins), followed by centrifugation under the same conditions. The erythrocyte suspension was taken by capillary $(0.02 \mathrm{ml})$ and transferred to a test tube where $10 \mathrm{ml}$ of isotonic sodium chloride solution was pre-introduced. The capillary was washed in the top layer of the solution and the contents of the test tube were thoroughly mixed. In this case $0.2 \%$ suspension of erythrocytes was obtained (Terskov \& Hitelzon, 1967).

Measurement of optical density of the solutions was carried by a photometer at $540 \mathrm{~nm}$ wavelength (cuvettes with $10 \mathrm{~mm}$ process soluteon thickness). Before the study, both cuvettes were filled for 5-10 min with hemolytic solution with the abovementioned concentration. The control cuvette was filled with $4 \mathrm{ml}$ of $0.85 \%$ sodium chloride, and the experimental one was filled with $2 \mathrm{ml}$ of hemolytic solution and $2 \mathrm{ml}$ of $0.2 \%$ erythrocytes' suspension added. Hemolytic with erythrocytes' suspension was stirred by pipette tip. The sample extinction was determined immediately after mixing. Extinction changes were recorded every 30 seconds until a constant indicator is reached, during 30 seconds (Golovakha et al., 2017).

The difference between the initial and final (after hemolysis) optical density is seen as $100 \%$ and the $\Delta \mathrm{E}$ percentage was calculated (the next extinction index was subtracted from previous one and seen as " $\mathrm{X}$ "), which reflects the relative percentage of non-hemolyzed erythrocytes every 30 seconds. This calculation excludes dependence of the results on the number of erythrocytes and hemoglobin concentration. The obtained data was depicted graphically. The horizontal axis reflects time from 0 and every 30 seconds, the ordinate axis - the erythrocytes' hemolysis percentage. The left side of the diagram indicates hemolysis of "old" erythrocyte populations, the central part with the peak is formed by the destruction of "mature" and partially "young" cells, the right side is the hemolysis result of only "young" erythrocytes (Terskov \& Hitelzon, 1967).

The population structure of the erythrocytes was determined by fractionation of sucrose density gradient by the I. Sizova method (Sizova et al., 1980). Blood samples were put into centrifuge tubes, with previously added heparin at $10 \mathrm{IU}$ per $10 \mathrm{ml}$ of blood. Plasma was separated by centrifugation (1,500 rpm for 20 minutes). The erythrocytes' suspension was washed three times by cooled to $4{ }^{\circ} \mathrm{C}$ (to prevent oxidation of lipoproteins) $0.85 \%$ sodium chloride solution followed by centrifugation under the same conditions.

The erythrocytes' suspension was taken by a $0.1 \mathrm{ml}$ pipette and moved to Florinski test tubes, previously filled with $0.9 \mathrm{ml}$ of isotonic sodium chloride solution. The pipette was washed in the upper layer of the solution and the tube content was thoroughly mixed (thus obtaining $10 \%$ erythrocytes suspension). $0.5 \mathrm{ml}$ of erythrocytes' suspension was introduced into the $45^{\circ}$ tilted column, and sucrose solution was put layer over layer on the column wall (the first layer - with the highest concentration, the last - with the lowest). It is provides the distribution of erythrocytes in different concentrations of sucrose, depending on the erythrocytes' age.

The column was carefully leveled at $90^{\circ}$ to avoid mixing of the sucrose layers, and every last layer was carefully separated into a separate graded tube (7 in total). Isotonic sodium chloride solution was added into each tube, totaling volume to $10 \mathrm{ml}$. All 7 tubes were thoroughly mixed and checked for the optical density.

Measurement of the solutions' optical density was carried by the photometer at $520 \mathrm{~nm}$ wavelength (cuvettes with $10 \mathrm{~mm}$ working layer thickness). A $0.85 \%$ sodium chloride solution was a control one. The received extinction amount was seen as $100 \%$, and each tube index was seen as " $\mathrm{X}$ " and thus calculating the percentage of a particular fraction. The indicators of the first three tests (in sucrose solutions of $30 \%, 26 \%$ and $22 \%$ concentrations) were added. The obtained result was a percentage indicator of the "old" erythrocytes' number. The same was done with the fourth and fifth indicators ( $18 \%$ and $14 \%$ solutions), by calculating the concentration of "mature" cells, while adding percentage of the sixth and the seventh results (10\% and 6\% sucrose solutions) and a relative indicator of the "young" population's content was obtained (Sizova et al., 1980; Wijk \& Solinge, 2005).

In the blood serum the following were determined: the content of the ferrum, the total and unsaturated ferrum-binding ability of the serum (TIBS, UIBS), the level of transferrin and the saturation of it by ferrum (ferrosine method).

Mathematical analysis of the study results was conducted in Statistica 6.0 (StatSoft Inc., USA). Differences between average values were considered statistically significant at $\mathrm{P}<0.05$ (ANOVA).

\section{Results}

Clinically, babesiosis in dogs was manifested by hyperthermia (up to $41.2{ }^{\circ} \mathrm{C}$ ), drowsiness, shaky stroke, anemia in the mucous membranes of the eyes and oral cavity, dull hair, thirst, vomiting. In sick animals there were: tachycardia, tachypnea, oliguria, yellow-brown urine. In dogs of first group (age up to 18 months), the number of erythrocytes was reduced and averaged $3.8 \pm 0.33 \mathrm{~T} / \mathrm{L}$, which is $57.6 \%$ less than in clinically healthy animals. Oligocythemia was found in all animals. In dogs of the second group, too, oligocythemia was established $-4.7 \pm$ $0.36 \mathrm{~T} / \mathrm{L}$ (minimal norm is $5.0 \mathrm{~T} / \mathrm{L}$ ). Along with oligocythemia in animals, anisocytosis and poikilocytosis have been observed, indicated dystrophic changes in the structural elements of the bone marrow.

We also found changes in the population composition of erythrocytes. In particular, the number of "old" erythrocytes in dogs of the first group on average was $15.4 \pm 2.46 \%$, which is almost three times more than in the clinically healthy animals $(\mathrm{P}<0.05)$. However, the most "old" populations of erythrocytes were found in older dogs (second group). In them, the number of "old" in the group on average was $27.9 \pm$ $4.98 \%$, which is 5.2 times more than in the clinically healthy animals $(\mathrm{P}<0.01)$. Such a number of "old" erythrocytes, obviously, is evidence of an increase in aging processes of "red" cells.

Unlike "old" populations, the number of "mature" red cells in patients of both groups did not differ from the number in clinically healthy animals ( $\mathrm{P}<0.5$, Table 1). The number of "young" forms of erythrocytes, compared with clinically healthy, in dogs with babesiosis, especially the second group, was reduced and averaged $35.0 \pm 5.80 \%$, which is $17.7 \%$ less than in clinically healthy animals. Reduction of "young" red blood cells is evidence of depletion of the "red" bone marrow and inhibition of adaptive processes for hemic hypoxia.

\section{Table 1}

Indices of the total number of erythrocytes and their population structure in $\operatorname{dogs}$

\begin{tabular}{lcccc}
\hline \multirow{2}{*}{$\begin{array}{c}\text { Animal } \\
\text { groups }\end{array}$} & Erythrocytes, & \multicolumn{3}{c}{ population structure of erythrocytes, \% } \\
\cline { 3 - 5 } & $\mathrm{T} / 1$ & "old" & "mature" & "young" \\
\hline Clinically healthy & $5.7-7.67$ & $1.6-11.3$ & $33.0-58.0$ & $35.2-62.3$ \\
$(\mathrm{n}=10)$ & $6.6 \pm 0.25$ & $5.4 \pm 1.12$ & $41.9 \pm 3.25$ & $52.7 \pm 2.59$ \\
Infected, age up to & $2.57-4.96$ & $6.2-25.5$ & $27.7-41.6$ & $35.1-56.2$ \\
1.5 years $(\mathrm{n}=10)$ & $3.8 \pm 0.33$ & $15.4 \pm 2.46$ & $36.8 \pm 1.38$ & $47.8 \pm 2.26$ \\
\hline \multicolumn{1}{c}{$\mathrm{P}<$} & 0.001 & 0.05 & 0.5 & 0.5 \\
\hline Infected, age & $2.52-7.75$ & $3.8-66.2$ & $19.7-56.0$ & $12.4-61.3$ \\
2-8 years $(\mathrm{n}=15)$ & $4.7 \pm 0.36$ & $27.9 \pm 4.98$ & $37.1 \pm 2.57$ & $35.0 \pm 5.80$ \\
\hline \multicolumn{1}{c}{$\mathrm{P}<$} & 0.01 & 0.01 & 0.5 & 0.05 \\
\hline
\end{tabular}

Changes in the population composition of erythrocytes also affect their osmotic (acid) resistance, since the time of hemolysis depends on their age, leads to the destruction of intracellular structures and lowering the resistance of the membrane to increased pressure inside the cell.

The analysis of the erythrograms (acid erythrocytes hemolysis) shows that the time of the main peak in dogs of the first group was $3.7 \mathrm{~min}$; its height was $20 \%$ (Fig. 1). The whole hemolysis of erythrocytes was completed in $6.5 \mathrm{~min}$. The time of hemolysis of "old" and "mature" erythrocytes in dogs of the first group was $3.5 \mathrm{~min}$, which is $2 \mathrm{~min}$ less, compared to clinically healthy dogs of the same age. It testifies to the rapid destruction of these populations as a result of the depletion of the structural and functional state of membranes of red blood cells. Regar- 
ding the hemolysis of the "young" red blood cells (right side of the graph), its duration in both patients and healthy dogs was $3 \mathrm{~min}$, but in animals with babesiosis invasion there was an additional peak indicating the unstable resistance of the membranes of "young" red blood cells to the action of hemolysis due to toxic effects products of microscopic parasites' catabolism.

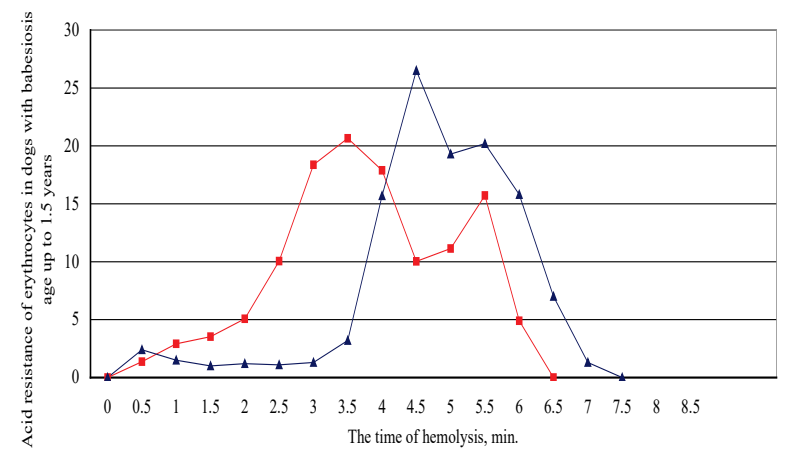

Fig. 1. Acid resistance of erythrocytes in dogs with babesiosis aged up to 1.5 years $(n=10)$

Analyzing the erythrograms of dogs of the second group (Fig. 2), it should be noted that the left side of the graph (hemolysis of the "old" and "mature" populations) was more acute and expired for $3 \mathrm{~min}$, while in healthy dogs, it was $2 \mathrm{~min}$ longer. It may indicate the blocking effect of invasive agents on the elements of the erythroid bone marrow sprout, inhibition of erythrocyte maturation processes and increased aging. The complete hemolysis time was $5.5 \mathrm{~min}$, which is $1.5 \mathrm{~min}$ less, compared to healthy dogs, indicating a change in the functional state of the membranes of the "young" populations.

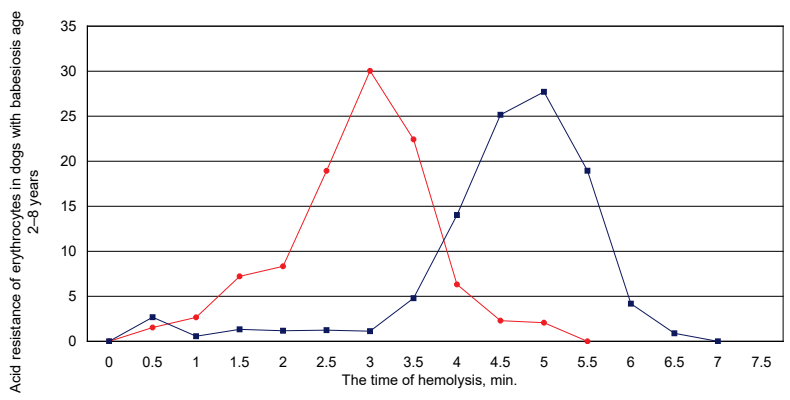

Fig. 2. Acid resistance of erythrocytes in dogs with babesiosis aged $2-8$ years $(n=15)$

The content of the respiratory blood enzyme (hemoglobin) in dogs with babesiosis was reduced. In particular, in young dogs (first group), its average number was $98.0 \pm 6.59 \mathrm{~g} / \mathrm{l}$, which is $38.0 \%$ less than in clinically healthy $(\mathrm{P}<0.001)$. Similar values of this chromoprotein were also found in dogs of the second group $(\mathrm{P}<0.001$, Table 2$)$. It should be noted that oligochromemia was established in 90.0 and $80.0 \%$ of dogs of the first and second groups, which testifies to the increased destruction of red blood cells. If the number of erythrocytes and hemoglobin content in dogs with babesiosis are reduced, then the indices of "red" blood, in particular, the $\mathrm{MCH}$, did not differ from the values in clinically healthy animals (Table 2).

One of the commonly used indicators of erythrocytopoesis is the hematocrit index, which determines the total volume of erythrocytes, characterizing certain types of anemia (Gutyj et al., 2017; Slivinska et al., 2018). In dogs with babesiosis, this indicator was lower than normal $(\mathrm{P}<0.01)$. It should be noted that low values of hematocrit were detected in $90.0 \%$ and $73.3 \%$ of dogs from the first and second groups, respectively.

Different forms of anemia can be diagnosed using an average volume of red blood cells (MCV). MCV in dogs should not exceed $80 \mu \mathrm{m}^{3}$. However, in some of the sick dogs of both the first and the second groups, the MCV was within the range of $80.2-101.3 \mu \mathrm{m}^{3}$. That is, in such cases there is an increased inflow into the peripheral blood of immature erythrocytes.

But, it is impossible to evaluate erythrocytopoesis without indicators of the ferrum-transferin complex, the basis of which is the ferrum. It is the element that plays an important role in the transfusion of oxygen and carboxylic acid in the cells of the body. The content of ferrum in blood serum of dogs with babesiosis on average did not differ from the values in clinically healthy animals $(\mathrm{P}<0.5$, Table 3$)$. However, a detailed analysis of the obtained values shows that some dogs $(60.0 \%$ and $66.7 \%$ respectively) exhibit hyposideremia, which indicates a low intake of ferrum into the body.

Table 2

Changes in erythrocytopoesis in dogs with babesiosis

\begin{tabular}{lcccc}
\hline \multicolumn{1}{c}{ Animal groups } & $\begin{array}{c}\text { Hemoglobin, } \\
\mathrm{g} / \mathrm{l}\end{array}$ & $\begin{array}{c}\text { Hematocrit } \\
\text { index, } \%\end{array}$ & $\begin{array}{c}\mathrm{MCH}, \\
\mathrm{fmol}\end{array}$ & $\begin{array}{c}\mathrm{MCV}, \\
\mathrm{mm}^{3}\end{array}$ \\
\hline Clinically healthy & $145.0-168.0$ & $46.0-57.0$ & $20.4-28.2$ & $64.6-82.5$ \\
$(\mathrm{n}=10)$ & $158.0 \pm 2.84$ & $50.0 \pm 1.46$ & $24.0 \pm 0.94$ & $74.8 \pm 2.29$ \\
Infected, age up to & $52,0-142.0$ & $19.0-35.0$ & $19.6-33.3$ & $58.1-101.2$ \\
1.5 years $(\mathrm{n}=10)$ & $98.0 \pm 6.59$ & $28.1 \pm 1.21$ & $26.4 \pm 1.86$ & $76.6 \pm 4.72$ \\
\hline \multicolumn{1}{c}{$\mathrm{P}<$} & 0.001 & 0.001 & 0.5 & 0.5 \\
\hline Infected, age & $72.0-148.0$ & $17.0-46.0$ & $18.2-30.8$ & $57.6-101.3$ \\
2-8 years $(\mathrm{n}=15)$ & $100.0 \pm 5.95$ & $30.8 \pm 2.33$ & $21.7 \pm 1.06$ & $65.9 \pm 2.44$ \\
\hline \multicolumn{1}{c}{$\mathrm{P}<$} & 0.001 & 0.01 & 0.2 & 0.05 \\
\hline
\end{tabular}

Table 3

Indicators of the ferrum-transferrin complex in dogs

\begin{tabular}{|c|c|c|c|c|}
\hline $\begin{array}{l}\text { Animal } \\
\text { groups }\end{array}$ & $\begin{array}{l}\text { Biometric } \\
\text { indicator }\end{array}$ & $\begin{array}{c}\text { Ferrum, } \\
\mu \mathrm{mol} / \mathrm{l}\end{array}$ & $\begin{array}{l}\mathrm{TIBC}, \\
\mu \mathrm{mol} / \mathrm{l}\end{array}$ & $\begin{array}{l}\mathrm{UIBC}, \\
\mu \mathrm{mol} / \mathrm{l}\end{array}$ \\
\hline \multirow{5}{*}{$\begin{array}{l}\begin{array}{l}\text { Clinically healthy } \\
(\mathrm{n}=10)\end{array} \\
\text { Infected, aged up to } \\
1.5 \text { years }(\mathrm{n}=10)\end{array}$} & \multirow{2}{*}{$\operatorname{Lim} M \pm m$} & $22.4-36.7$ & $62.5-83.2$ & $34.6-48.7$ \\
\hline & & $28.3 \pm$ & $70.8 \pm 2.63$ & $42.5 \pm 1.64$ \\
\hline & \multirow{2}{*}{$\operatorname{Lim} \mathrm{M} \pm \mathrm{m}$} & $16.8-40.3$ & $60.6-91.7$ & $41.3-72.8$ \\
\hline & & $23.6 \pm 2.70$ & $80.2 \pm 2.96$ & $56.6 \pm 4.09$ \\
\hline & $\mathrm{P}<$ & 0.2 & 0.05 & 0.05 \\
\hline \multirow{3}{*}{$\begin{array}{l}\text { Infected, aged } \\
2-8 \text { years }(n=15)\end{array}$} & \multirow{2}{*}{$\operatorname{Lim} \mathrm{M} \pm \mathrm{m}$} & $17.8-39.6$ & $76.3-111.4$ & $43.1-89.4$ \\
\hline & & $26.6 \pm 2.52$ & $89.5 \pm 3.45$ & $62.9 \pm 2.90$ \\
\hline & $\mathrm{P}<$ & 0.5 & 0.01 & 0.001 \\
\hline
\end{tabular}

In the rest of the animals ( $30.0 \%$ and $26.7 \%$, respectively), hypersideremia was found ( $>35 \mu \mathrm{mol} / \mathrm{l}$ ), which obviously indicates an increased accumulation of ferrum in the blood for the destruction of red blood cells. But it is important that the value of the content of the ferrum cannot on its own reflect the state of its exchange. Therefore, it is important to determine other indicators of its metabolism, in particular, TIBC (indicating the content of a non-protein-transferrin-bound ferrum) and UIBC (toxic level indicator of the ferrum).

TIBC in dogs with babesiosis was elevated in the first and second group by $13.3 \%$ and $26.6 \%$ respectively $(\mathrm{P}<0.01)$. High values of TIBC indicate dystrophic changes in the transferrin receptor apparatus, which leads to a reduced transport of the ferrum from the depot to the bone marrow, enhanced erythrocyte hemolysis, and the accumulation of free ferrum. An indicator of the last one is the UIBC, which indicates the non-transferring pool of the ferrum. In dogs with babesiosis, UIBC averaged $56.6 \pm 4.09$ and $62.9 \pm 2.90 \mu \mathrm{mol} / \mathrm{l}$ in the first and second groups, respectively, which is by $33.2 \%$ and $48.0 \%$ more than in clinically healthy animals $(\mathrm{P}<0.05$ and $\mathrm{P}<0.001)$. This value indicates the accumulation of toxic (free) ferrum and reduced binding of the protein transferrin to the trace element.

It is not advisable to evaluate the exchange of a ferrum without determining the content of transferrin in serum and its saturation with ferrum. The content of transferrin in dogs with babesiosis was elevated and was in the first and second group 3.6 \pm 0.13 and $4.0 \pm 0.13 \mathrm{~g} / \mathrm{l}$, respectively.

In contrast to the amount of transferrin, the coefficient of its saturation with ferrum was lower, compared with healthy animals, and was in young dogs (first group) $-29.5 \pm 3.17 \%$, in older (the second group) $29.8 \pm 2.66 \%$ ( $(\mathrm{P}<0.05$, Table 4$)$. Reduced saturation (less than $30 \%$ ) of transferrin with ferrum was detected in $30.0 \%$ and $33.3 \%$ of animals, respectively, indicating a low synthesis of the structure of the protein molecule of transferrin in the liver and slow transport of the trace element to the depot and bone marrow. 
Table 4

Indicators of the ferrum-transferrin complex in dogs

\begin{tabular}{|c|c|c|c|}
\hline $\begin{array}{l}\text { Animal } \\
\text { groups }\end{array}$ & $\begin{array}{l}\text { Biometric } \\
\text { indicator }\end{array}$ & $\begin{array}{l}\text { Transferrin } \\
\text { content, g/l }\end{array}$ & $\begin{array}{l}\text { Coefficient of transferrin's } \\
\text { saturation with ferrum, \% }\end{array}$ \\
\hline $\begin{array}{l}\text { Clinically healthy } \\
(\mathrm{n}=10) \\
\text { Infected, age up to } \\
1.5 \text { years }(\mathrm{n}=10)\end{array}$ & $\operatorname{Lim} M \pm m$ & $\begin{array}{c}2.79-3.72 \\
3.20 \pm 0.12 \\
2.71-4.10 \\
3.60 \pm 0.13 \\
\end{array}$ & $\begin{array}{l}33.30-44.60 \\
39.90 \pm 1.41 \\
19.80-48.70 \\
29.50 \pm 3.17 \\
\end{array}$ \\
\hline & $\mathrm{P}<$ & 0,05 & 0,05 \\
\hline $\begin{array}{l}\text { Infected, age } \\
2-8 \text { years }(n=15)\end{array}$ & $\operatorname{Lim} M \pm m$ & $\begin{array}{l}3.41-4.98 \\
4.0 \pm 0.13 \\
\end{array}$ & $\begin{array}{l}17.60-43.50 \\
29.80 \pm 2.66\end{array}$ \\
\hline & $\mathrm{P}<$ & 0.01 & 0.05 \\
\hline
\end{tabular}

\section{Discussion}

The development of babesiosis in dogs is a complex process which is determined by a number of biological, natural-climatic and socioeconomic factors (Iguchi et al., 2014). The pathogenesis of this disease is determined by the specific type of pathogen and the corresponding reactions occurring in the organism of the affected animal, which, in turn, depend on the biology and life cycle of the Babesia canis and the conditions in which the interaction of the macro- and microorganism occurs (Al Izzi et al., 2013; Bajer et al., 2016; Piane et al., 2016). The peculiarity of the pathogenesis of the disease is the reproduction of the causative agent of babesiosis in the organism of a susceptible animal inside the erythrocytes of the capillaries in the internal organs, and then in the erythrocytes of the blood stream. Parasites are feeding in red blood cells through osmosis. The metabolites of parasites that have been excreted during this, cause a violation of the function of the organs of the hematopoesis of the host, disturbed blood circulation, etc. That is why the leading role in pathogenesis is given to the destruction of erythrocytes and as a consequence - the development of anemia. The destructtion of red blood cells occurs in the spleen, which leads to the appearance of blood in the free hemoglobin, which is excreted in the urine in the unchanged form or in the form of urobilinogen. Thus, for babesiosis, changes in the functions of the circulatory system, especially the morphological composition of blood, are adaptive (Di Mauro \& Schoeffler, 2016).

As a result of hemoglobin destruction, endogenous siderosis develops, as indicated by the increased content of ferrum in serum. This can cause the trapping of the trace element in the liver and kidneys and the development of hemochromatosis. Thus, in dogs with babesiosis, regenerative-macrocytic anemia develops, which is accompanied by oligocythemia, oligochromia, macrocytosis, reticulocytosis, thrombocytopenia, and elevated erythrocyte sedimentation rate (ESR). At the same time, the decrease in the number of erythrocytes prevailed over the decrease in the content of hemoglobin, which gives grounds to consider such a process as hemolytic (Sunaga et al., 2013).

In dogs with babesiosis at the first stages of the disease, poikilocytosis with the presence of echinocytes and acanthocytes (spherical stellate cells), and stomatocytes (pelori in the form of a slit) were detected. The third stage of the disease was characterized by schizocytes (fractures of red blood cells) and basophilic granularity of erythrocytes.

Hypoxia and intoxication caused by metabolites of babesia lead to dystrophic changes in hepatocytes and disturbance of their bilirubin and protein-synthesizing functions (Crnogaj et al., 2017). It is known from literary sources that merozoites of the pathogen bind to the receptors of the caudal-lateral surface in the hepatocytes due to the presence of a protein in them, which is homologous to the connecting portion of the thrombospondin in hepatocytes. Inside the liver cell, the parasite rapidly breeds and merozoites, formed in large numbers, break the hepatocyte. Bloodparasites have a destructive effect on the vessels, including the vessels of the portal system. Violation of blood circulation in the liver leads to increased portal pressure accordingly the slowing of blood flow (Zygner et al., 2012; Sunaga et al., 2013).

Pathomorphological changes in the liver are characterized by a discomplexation of the liver beams, granular dystrophy, hepatocyte necrosis. Due to babesiosis, a mixed - hemolytic-parenchymal jaundice with a sign of cholestasis develops. The severity of the disease is determined by the presence and intensity of jaundice. The most informative indicator of the early stages of the development of liver disease is hyperfermentemia; the more severe degree of damage to hepatocytes is shown by hypo- and dysproteinemia.

\section{Conclusions}

In dogs of service breeds from different age groups with babesiosis we found oligocytemia with anisocytosis and poikilocytosis, oligochromemia, decreased hematocrit index and macrocytosis. We detected significant changes in the morpho-functional state of erythrocytes in dogs of both age groups due to the catabolic effect of ultramicroscopic invasion on their membranes and the processes of erythrocytopoesis. In dogs with babesiosis, the population (age) composition of erythrocytes varies: the number of "old" erythrocytes increases (they are rapidly destroyed) and the "young" forms of red blood cells (which do not completely provide tissue with oxygen) are reduced. It is, in turn, reflected in the acid resistance of the "red" cells and reduction in the time of hemolysis. The undeniable proof of the work of erythron and processes of transfusion of gases in the body is the ferrum-transferrin complex. As a result of its study in dogs with babesiosis from both age groups, an increase in the level of free ferrum (UIBC) was found and a reduction in the saturation of transferrin with this trace element, which makes it impossible to form hemoglobin molecules in the bone marrow.

\section{References}

Al Izzi, S., Martin, D. S., Chan, R. Y., \& Leutenegger, C. M. (2013). Babesia canis vogeli, Ehrlichia canis, and Anaplasma platys infection in a dog. Veterinary Clinical Pathology, 42(4), 471-475.

Bajer, A., Mierzejewska, E. J., Rodo, A., \& Welc-Falęciak, R. (2014). The risk of vector-borne infections in sled dogs associated with existing and new endemic areas in Poland. Part 2: Occurrence and control of babesiosis in a sled dog kennel during a 13-year-long period. Veterinary Parasitology, 202(3-4), 234-240

Bajer, A., Mierzejewska, E. J., Rodo, A., Bednarska, M., Kowalec, M., \& WelcFalęciak, R. (2014). The risk of vector-borne infections in sled dogs associated with existing and new endemic areas in Poland: Part 1: A population study on sled dogs during the racing season. Veterinary Parasitology, 202(3-4), 276-286.

Bajer, A., Rodo, A., Mierzejewska, E. J., Tołkacz, K., \& Welc-Faleciak, R. (2016). The prevalence of Dirofilaria repens in cats, healthy dogs and dogs with concurrent babesiosis in an expansion zone in central Europe. BMC Veterinary Research, 12(1), 183.

Bartnicki, M., Łyp, P., Dębiak, P., Staniec, M., Winiarczyk, S., Buczek, K., \& Adaszek, Ł. (2017). Cardiac disorders in dogs infected with Babesia canis. Polish Journal of Veterinary Sciences, 20(3), 573-581.

Crnogaj, M., Cerón, J. J., Šmit, I., Kiš, I., Gotić, J., Brkljačić, M., Matijatko, V., Rubio, C. P., Kučer, N., \& Mrljak, V. (2017). Relation of antioxidant status at admission and disease severity and outcome in dogs naturally infected with Babesia canis canis. BMC Veterinary Research, 13(1), 114

Davitkov, D., Vucicevic, M., Stevanovic, J., Krstic, V., Tomanovic, S., Glavinic, U., \& Stanimirovic, Z. (2015). Clinical babesiosis and molecular identification of Babesia canis and Babesia gibsoni infections in dogs from Serbia. Acta Veterinaria Hungarica, 63(2), 199-208.

Di Cicco, M. F., Downey, M. E., Beeler, E., Marr, H., Cyrog, P., Kidd, L., Diniz, P. P, Cohn, L. A., \& Birkenheuer, A. J. (2012). Re-emergence of Babesia conradae and effective treatment of infected dogs with atovaquone and azithromycin. Veterinary Parasitology, 187(1-2), 23-27.

Di Mauro, F. M., \& Schoeffler, G. L. (2016). Point of care measurement of lactate. Topics in Companion Animal Medicine, 31(1), 35-43.

Eichenberger, R. M., Riond, B., Willi, B., Hofmann-Lehmann, R., \& Deplazes, P. (2016). Prognostic markers in acute Babesia canis infections. Journal of Veterinary Internal Medicine, 30(1), 174-182.

Goddard, A., Leisewitz, A. L., Kristensen, A. T., \& Schoeman, J. P. (2015) Platelet activation and platelet-leukocyte interaction in dogs naturally infected with Babesia rossi. Veterinary Journal, 205(3), 387-392.

Golovakha, V. I., Piddubnyak, O. V., Sliusarenko, S. V., Slivinska, L. G., Maksymovych, I. A., Shcherbatyy, A. R., \& Gutyj, B. V. (2017). Acid resistance and population structure of erythrocytes in trotter horses during and after exercise. Regulatory Mechanisms in Biosystems, 8(4), 623-627.

Gutyj, B., Martyshchuk, T., Bushueva, I., Semeniv, B., Parchenko, V., Kaplaushenko, A., Magrelo, N., Hirkovyy, A., Musiy, L., \& Murska, S. (2017). Morphological and biochemical indicators of blood of rats poisoned by car- 
bon tetrachloride and subject to action of liposomal preparation. Regulatory Mechanisms in Biosystems, 8(2), 304-309.

Gutyj, B., Khariv, I., Binkevych, V., Binkevych, O., Levkivska, N., Levkivskyj, D., \& Vavrysevich, Y. (2017). Research on acute and chronic toxity of the experimental drug Amprolinsyl. Regulatory Mechanisms in Biosystems, 8(1), 41-45.

Iguchi, A., Shiranaga, N., Matsuu, A., \& Hikasa, Y. (2014). Efficacy of Malarone(®) in dogs naturally infected with Babesia gibsoni. Journal of Veterinary Medical Science, 76(9), 1291-1295.

Jain, K. J., Lakshmanan, B., Syamala, K., Praveena, J. E., \& Aravindakshan, T. (2017). High prevalence of small Babesia species in canines of Kerala, South India. Veterinary World, 10(11), 1319-1323.

Liu, M., Cao, S., Vudriko, P., Suzuki, H., Soma, T., \& Xuan, X. (2016). Babesia gibsoni internal transcribed spacer 1 region is highly conserved amongst isolates from dogs across Japan. Journal of Veterinary Medical Science, 78(5), 863-865.

Lobetti, R., Kirberger, R., Keller, N., Kettner, F., \& Dvir, E. (2012). NT-ProBNP and cardiac troponin I in virulent canine babesiosis. Veterinary Parasitology, 190(3-4), 333-339.

Piane, L., Théron, M. L., Aumann, M., \& Trumel, C. (2016). Spurious reticulocyte profiles in a dog with babesiosis. Veterinary Clinical Pathology, 45(4), 594-597.

Rojas, A., Rojas, D., Montenegro, V., Gutiérrez, R., Yasur-Landau, D., \& Baneth, G. (2014). Vector-borne pathogens in dogs from Costa Rica: First molecular description of Babesia vogeli and Hepatozoon canis infections with a high prevalence of monocytic ehrlichiosis and the manifestations of co-infection. Veterinary Parasitology, 199(3-4), 121-128.

Salem, N. Y., \& Farag, H. S. (2014). Clinical, hematologic, and molecular findings in naturally occurring Babesia canis vogeli in egyptian dogs. Veterinary Medicine International, Article ID 270345.

Sizova, I. A., Kamenskaja, V. V., \& Fedjakov, V. I. (1980). Bezapparaturnyj sposob frakcionirovanija krasnyh kletok krovi $\mathrm{v}$ gradiente plotnosti saharozy [The nonparametric method of fractionation of red blood cells in a sucrose density gradient]. Izvestija Sibirskogo Otdelenija Akademii Nauk SSSR, 3(15), 119-122 (in Russian).
Slivinska, L., Shcherbatyy, A., Gutyj, B., Lychuk, M., Fedorovych, V., Maksymovych, I., Rusyn, V., \& Chernushkin, B. (2018). Parameters of erythrocytopoiesis, acid resistance and population composition of erythrocytes of cows with chronic hematuria. Ukrainian Journal of Ecology, 8(1), 379-385.

Sunaga, F., Arai, S., Itoh, S., \& Taharaguchi, S. (2014). Protective efficacy of Babesia gibsoni culture-derived exoantigens against the challenge infection in dogs. Parasitology Research, 113(5), 1681-1686.

Sunaga, F., Taharaguchi, S., Arai, S., Itoh, S., \& Kanno, Y. (2013). Virulence attenuation of Babesia gibsoni by serial passages in vitro and assessment of the protection provided by the immunization against the passaged isolate in dogs. Veterinary Parasitology, 197(3-4), 565-570.

Tasaki, Y., Miura, N., Iyori, K., Nishifuji, K., Endo, Y., \& Momoi, Y. (2013). Generalized alopecia with vasculitis-like changes in a dog with babesiosis. Journal of Veterinary Medical Science, 75(10), 1367-1369.

Terskov, I. A., \& Hitelzon, I. I. (1967). Znachenie dispersionnyh metodov analiza jeritrocitov $\mathrm{v}$ norme $\mathrm{i}$ patologii [The value of dispersion methods for erythrocytes analysis in norm and pathology]. Voprosy Biofiziki, Biohimii i Patologii Jeritrocitov. Nauka, Moscow. Pp. $41-48$ (in Russian).

Wang, J., Zhang, J., Kelly, P., Zheng, X., Li, M., You, J., Huang, K., Qiu, H., Wang, Y., Zhang, R., Li, J., Dong, J., Feng, Y., Zhou, J., \& Wang, C. (2018). First description of the pathogenicity of Babesia vogeli in experimentally infected dogs. Veterinary Parasitology, 253, 1-7.

Wijk, R., \& Solinge, W. (2005). The energy-less red cell is lost: Erythrocyte enzyme abnormalities of glycolysis. Blood, 106(13), 40344042.

Ybañez, R. H. D., Ybañez, A. P., Arnado, L. L. A., Belarmino, L. M. P., Malingin, K. G. F., Cabilete, P. B. C., Amores, Z. R. O., Talle, M. G., Liu, M., \& Xuan, X. (2018). Detection of Ehrlichia, Anaplasma, and Babesia spp. in dogs of Cebu, Philippines. Veterinary World, 11(1), 14-19.

Zygner, W., Gójska-Zygner, O., Norbury, L. J., \& Wedrychowicz, H. (2012). Increased AST/ALT ratio in azotaemic dogs infected with Babesia canis. Polish Journal of Veterinary Sciences, 15(3), 483-486. 